DOI 10.18551/rjoas.2021-06.15

\title{
THE EFFECT OF TRANSFORMATIONAL LEADERSHIP ON WORK ENGAGEMENTS MEDIATED BY MEANINGFUL WORK AND PERSONAL RESOURCES: A STUDY ON EMPLOYEES OF AIRNAV INDONESIA DENPASAR BRANCH
}

\author{
Asmaluddin*, Sintaasih Desak Ketut \\ Faculty of Economics and Business, University of Udayana, Bali, Indonesia \\ *E-mail: asmaluddincontroller89@gmail.com
}

\begin{abstract}
This study aims to explain the role of meaningful work and personal resources in mediating the relationship between transformational leadership and work engagement. The study was conducted at AirNav Indonesia Denpasar Branch with a sample of 117 employees. The sample was determined using the proportionate random sampling method. Data collection methods used are interviews and questionnaires. Data were analyzed using SEM (Structural Equation Modeling) with the PLS (Partial Least Square) approach. The results of this study indicate that transformational leadership, meaningful work, and personal resources have a positive and significant effect on work engagement; transformational leadership has a positive and significant effect on meaningful work and personal resources; meaningful work and personal resources act as partial mediators on the effect of transformational leadership on work engagement. This can have practical implications for leaders to implement and improve transformational leadership in order to increase meaningful work and personal resources for employees so as to increase work engagement in the company.
\end{abstract}

\section{KEY WORDS}

Transformational leadership, meaningful work, personal resources, work engagement.

The era of globalization requires companies to optimize all their resources to achieve their goals. One of the important resources in achieving these goals is human resources (HR) or employees. The important role of employees in achieving both short-term and longterm goals is to create added value for the company. Companies are required to be able to make employees feel engaged in each work area to fully engage, develop, and express all their ideas and abilities. A sense of engagement will make employees feel valued, motivated, and strive to make a positive contribution to improving their performance and company performance.

Work engagement is the effort of organizational members to fully commit themselves to their roles in the work in the company (Kahn, 1990). Schaufeli et al. (2002) and Schaufeli (2012) define work engagement as a positive, satisfying, and work-related state of mind characterized by vigor, dedication, and absorption. A good level of work engagement is conceptualized and characterized by a high level of energy and a strong identification with one's work (Bakker and Demerouti, 2008).

Work engagement not only makes employees make more positive contributions but also makes them have high loyalty thereby reducing the desire to leave the company voluntarily (Macey and Schneider, 2008). Employees can stay in a company if they feel attached to the company so that they are comfortable and happy when working. The feeling of comfort and pleasure comes from various factors that motivate employees in the company. Besides being able to increase motivation for employees, Siswanto and Lestari (2019) add that work engagement can also increase employee responsibility and affect employee performance in achieving organizational goals.

The level of work engagement is a concern for the Indonesian Aviation Navigation Service Provider Agency or known as AirNav Indonesia. AirNav Indonesia is the only stateowned company (BUMN) engaged in aviation navigation services. Based on PP No. 77 of 2012, the purpose and objective of establishing AirNav Indonesia is to provide aviation navigation services under applicable standards to achieve flight efficiency and effectiveness 
in the national and international scope. As a business entity, the benchmark for AirNav Indonesia's performance is seen from the safety supported by human resources, equipment, procedures, and so on, all of which must follow developments and standards that are strictly regulated in the Civil Aviation Safety Regulations (CASR).

AirNav Indonesia, which is headquartered in Tangerang, has one of the branch offices, namely the AirNav Indonesia Denpasar Branch. AirNav Indonesia Denpasar Branch realizes the importance of employees in the survival of the company as a provider of national and international standard flight navigation services. Employees as individuals have an important role in determining the achievement of organizational goals. One of the bases for achieving organizational goals is employee performance. So AirNav Indonesia Denpasar Branch needs to be supported by employees who have a high sense of attachment to achieve the expected performance and have a competitive advantage.

Based on the results of the work engagement pre-survey of 30 employees in the Administration and Finance Unit (ADM); Safety, Security, and Standardization Unit (K2S); Operations Unit - Air Traffic Controller (ATC); Operations Unit - Aviation Communications (ACO); Operations Unit - Air Traffic Flow Management (ATFM); Engineering Unit - CNS and Automation (CNSA); and Engineering Unit - Supporting (ESS) obtained a total work engagement score of AirNav Indonesia Denpasar Branch of 3.93. This tabulation gives the meaning that the work engagement is classified as high. However, there are still some items on the work engagement indicator that have low scores. This will be an important issue because a very high level of work engagement is one of the contributing factors in improving employee performance.

The results of the pre-survey showed that AirNav Indonesia Denpasar branch employees still seemed unable to work for very long periods of time at certain times (vigor). This can be seen from the average score of the item "able to work for a very long period of time at a certain time" which is the lowest, at 2.70 (63.3 percent). This tabulation means that 63.3 percent of AirNav Indonesia Denpasar Branch employees state that they are unable to work for a very long period of time at certain times.

The results of the pre-survey showed that AirNav Indonesia Denpasar branch employees seem to feel less comfortable working for long periods of time and not enjoying the atmosphere at work (absorption). This can be seen from the average score of the item "feel happy when working for a long time" which is the lowest, at 2.70 (50 percent). This tabulation means that 50 percent of AirNav Indonesia Denpasar Branch employees stated that they are not happy to work for long periods of time. Followed by the average score of the item "always enjoy the atmosphere at work" of 3.00 (46.7 percent). This tabulation means that 46.7 percent of AirNav Indonesia Denpasar Branch employees stated that they did not enjoy the atmosphere at work.

The factors that influence work engagement consist of the work itself, the work environment, the opportunity for self-development, the opportunity to contribute, organizational commitment, management quality, and leadership (Armstrong, 2011: 203). Leadership is the process of influencing others to understand and agree on what is needed in doing tasks and how to do that task, as well as a process to facilitate individual and group efforts to achieve common goals (Yukl, 2015: 9). One form of leadership style, namely transformational leadership. Yukl (2015: 316) states that transformational leadership is a leadership style possessed by a leader, where employees feel trust, admiration, loyalty, and respect for the leader, and are also motivated to do more things than expected.

Transformational leadership is stated to have a significant effect on work engagement by Ghadi et al. (2013) in their research using the GTL (Global Transformational Leadership) scale in measuring the dimensions of transformational leadership. Employees who have a transformed leader are more likely to be energetic, dedicated, and fun at work. In addition, Maulana and Verawati (2014) used the MLQ (Multifactor Leadership Questionnaire) scale in measuring the dimensions of transformational leadership, which stated that transformational leadership also had a significant effect on work engagement among company employees, the Corporate Law function of PT. Pertamina (Persero). It was further explained that the 
higher effectiveness of transformational leadership occurs when leaders have high abilities and skills in carrying out leadership functions so that it will increase work engagement.

Transformational leadership is stated to have a significant effect on work engagement in public sector organizations by Afiani et al. (2019). The effectiveness of transformational leadership can increase work attachments and vice versa, if transformational leadership is not effective, work attachments will not increase. In line with this, Handayani and Pitoyo's research (2018) also states that transformational leadership has a significant effect on work engagement. This is possible because leaders have a high level of caution in listening and meeting the needs expected by their followers, leaders also apply good coaching and mentoring to their followers by providing job challenges so that followers can actualize themselves better. It is further explained that existing transformational leadership is shown by leaders who provide a strong shared vision and mission so that followers can identify the leader's goals well.

A strong transformational leadership role creates a strong commitment from followers so that they feel engaged in work. This is evidenced by the high absorption of followers of the experience and knowledge provided by the leadership, high dedication, resilience, and strength at work. In other words, the transformational leadership applied by the leadership makes employees more attached to the company, so that it will make a positive contribution to company performance (Mat et al., 2019; Balwant et al., 2020). Therefore, the company is expected to pay attention to the level of work engagement to increase the desire of employees to last longer and contribute positively to the current company.

In addition to transformational leadership, Siahaan and Gatari (2020) state that a factor that has an important contribution in increasing work engagement is meaningful work. A company leader needs to know whether the work done by employees has meaning for the employee or not. This is because employees may think that this work is important so that they must work seriously or they may think otherwise like this job is not important so that they do not work seriously. Meaningful work is an individual's way of expressing meaning and purpose in carrying out work activities that cover most of the working hours (Chalofsky, 2003).

Steger et al. (2012) define meaningful work as making a job that has meaning so that it can make an optimal contribution to the organization. In addition, meaningful work is also defined as finding a goal in a job that is bigger than the extrinsic result of the work, so that an employee will feel that his work is meaningful and has an attachment to the job (Arnold et al., 2007; Ghadi et al., 2013). Meaningful work becomes important for employees because employees who find meaning in work tend to be more satisfied, more engaged, and in turn, will be more productive (Geldenhuys et al., 2014).

Research by Ghadi et al. (2013) stated that meaningful work not only has a direct and positive effect on work engagement but also acts as a partial mediator on the relationship between transformational leadership and work engagement. The existence of transformational leadership allows employees to see work as part of a larger goal, consider work important and meaningful, increase motivation, and control emotions so that employees will feel more attached to their work in the organization.

In line with this, Handayani and Pitoyo (2018) also state that meaningful work acts as a partial mediator in the relationship between transformational leadership and work engagement. On the indirect effect, transformational leadership involves the meaningful work of each of its followers informing work engagement. This is because understanding work becomes something very meaningful, such as how important work is to do, the importance of contributing to the company, the importance of responsibility, and what form of pride you want to achieve. Transformational leadership can help followers find meaning by increasing the intrinsic quality of the work itself or the work environment, by training and giving advice to followers, increasing followers' self-actualization, always conveying a common vision, and enhancing a useful mission.

Rahman (2015) states that a leader with a transformational style can influence the cognitive and affective aspects of his followers. In the cognitive aspect, meaningful work will affect the performance of followers, while the affective aspect will reduce follower cynicism 
about organizational change. This is in accordance with Chalofsky (2003) which states that meaningful work leads to emotional, cognitive, and behavioral aspects of employees. In other words, a leader must be able to make followers have a sense of meaningful work, motivate, and stimulate followers intellectually so that followers feel valued and more motivated. Therefore, transformational leadership will allow employees to see work as part of a larger goal, consider work to be important and meaningful, to increase motivation and control emotions so that employees will feel more attached to their work in the organization (Ghadi et al. al., 2013; Pitoyo and Sawitri, 2016; Handayani and Pitoyo, 2018; Demirtas et al., 2019).

Another factor that influences work engagement is personal resources (Bakker and Demerouti, 2007). Hobfoll et al. (2003) define personal resources as a positive selfevaluation that is related to joy and leads to the individual's feelings about his ability to control and have a positive impact on his environment. In addition, personal resources are also defined as psychological capital which consists of several resources such as personal conditions that can be used to predict desired work-related outcomes (Wingerden et al., 2015). Personal resources are also considered as an internal factor that influences the level or value of subjective well-being of a person or individual (Luthans et al., 2007).

Existing research shows that personal resources serve as important predictors of work engagement. This is because the more significant personal resources are, the more individuals are intrinsically motivated to pursue goals, which results in higher performance (Bakker et al., 2008). Sofiah and Kurniawan (2019) and Xanthopoulou et al. (2009) stated that engaged employees have a very strong desire, believe that they can meet the demands faced in various contexts (self-efficacy). In addition, engaged employees tend to do something and believe that they will get good results in their lives (optimism), and believe that they can satisfy their needs by participating in various roles in the organization (organizational-based self-esteem).

Personal resources also act as mediators on the influence of transformational leadership on work engagement (Heuvel et al., 2010; Bakker et al., 2011; Handayani and Pitoyo, 2018). Furthermore, Handayani and Pitoyo (2018) explain that under the indirect influence, transformational leadership can increase followers' sense of optimism in forming work attachments. Strong optimism in followers produces strength in work that will generate positive energy so that when facing problems at work, followers do not easily give up or experience stress in solving problems that occur at work. This will also allow followers to be more dedicated to their work. In addition, transformational leadership can also increase follower self-confidence by involving followers in innovative and creative problem solving, as well as opening up leadership in sharing knowledge and experiences as well as increasing follower absorption for self-improvement and the company.

Based on this description, this study will discuss further the effect of transformational leadership on work engagement mediated by meaningful work and personal resources on AirNav Indonesia employees Denpasar Branch. Based on the background, the following hypothesis is formulated:

$\mathrm{H1}$ : Transformational leadership has a significant effect on work engagement;

$\mathrm{H} 2$ : Meaningful work has a significant effect on work engagement;

H3: Personal resources have a significant effect on work engagement;

$\mathrm{H} 4$ : Transformational leadership has a significant effect on meaningful work;

H5: Transformational leadership has a significant effect on personal resources;

H6: Meaningful work acts as a mediator on the effect of transformational leadership on work engagement;

H7: Personal resources act as mediators on the effect of transformational leadership on work engagement.

\section{METHODS OF RESEARCH}

This research is associative causality research using a quantitative approach. The scope of this research was carried out by the Denpasar branch office of AirNav 
Indonesia, which is located at Jalan I Gusti Ngurah Rai, No. 1 Tuban, Badung in 2021. The data used in this study are quantitative data and qualitative data. The quantitative data used are data on the number of employees, age, gender, latest education, years of service, number of respondents, and scores of respondents' answers. The qualitative data used was an overview and profile of the AirNav Indonesia office Denpasar branch.

The population in this study were all employees of AirNav Indonesia Denpasar Branch, totaling 165 people with a sample of 117 people. Sampling in this study used a proportionate random sampling technique, namely determining the number of samples in each unit by determining the proportion according to the number of employees in each existing work unit.

Data collection was carried out using interview instruments and questionnaires which were distributed online via google form. The scale used in this study is the Likert scale. This study uses validity and reliability tests to ensure that the questionnaire produces valid and reliable data before proceeding to the next stage. The analysis technique used is Structural Equation Modeling (SEM) with Partial Least Square (PLS).

\section{RESULTS AND DISCUSSION}

Testing the validity of the research instrument was carried out to measure whether or not a questionnaire was valid. The questionnaire is said to be valid if it has a correlation coefficient ( $r$ ) 0.30. All statement items on the research instrument used to measure the variables of transformational leadership, meaningful work, personal resources, and employee engagement have a correlation coefficient value greater than 0.30 . This means that the statement item is valid and suitable to be used as a research instrument.

Table 1 - Characteristics of Respondents

\begin{tabular}{|c|c|c|c|c|}
\hline No. & Characteristics & Classification & Freq. (people) & Percentage (\%) \\
\hline \multirow[t]{2}{*}{1} & Gender & Man & 71 & 60,7 \\
\hline & & Woman & 46 & 39,3 \\
\hline Total & & & 117 & 100,0 \\
\hline \multirow[t]{5}{*}{2} & Age & $20-25$ y.o & 15 & 12,8 \\
\hline & & $26-30$ y.o & 50 & 42,7 \\
\hline & & $31-35$ y.o & 27 & 23,1 \\
\hline & & $36-40$ y.o & 7 & 6,0 \\
\hline & & $>40$ y.o & 18 & 15,4 \\
\hline Total & & & 117 & 100,0 \\
\hline \multirow[t]{4}{*}{3} & Education & DII & 3 & 2,6 \\
\hline & & DIII & 62 & 53,0 \\
\hline & & DIV/S1 & 49 & 41,9 \\
\hline & & S2 & 3 & 2,6 \\
\hline Total & & & 117 & 100,0 \\
\hline \multirow[t]{7}{*}{4} & Work Unit & ADM & 7 & 6,0 \\
\hline & & K2S & 4 & 3,4 \\
\hline & & Operation - ATC & 53 & 45,3 \\
\hline & & Operation - ATFM & 7 & 6,0 \\
\hline & & Operation - ACO & 14 & 12,0 \\
\hline & & Engineering - CNSA & 21 & 17,9 \\
\hline & & Engineering - ESS & 11 & 9,4 \\
\hline Total & & & 117 & 100,0 \\
\hline \multirow[t]{5}{*}{5} & Work Period & $<5$ years & 33 & 28,2 \\
\hline & & 5-10 years & 55 & 47,0 \\
\hline & & $11-15$ years & 10 & 8,5 \\
\hline & & $16-20$ years & 8 & 6,8 \\
\hline & & $>20$ years & 11 & 9,4 \\
\hline Total & & & 117 & 100,0 \\
\hline
\end{tabular}

Source: Primary data processed, 2021.

Testing the reliability of the research instrument was conducted to measure the extent to which the questionnaire used in the study could be trusted or relied on. The reliability test was carried out by calculating Cronbach's Alpha. A construct or variable is said to be reliable if it has a Cronbach's Alpha value $>0.70$. The number of respondents in this reliability test is 30 samples. All research instruments have Cronbach's Alpha coefficients greater than 0.70 . 
This means that all variables have met the requirements of reliability or reliability so that they can be used as research instruments.

Respondents are described in general by presenting their characteristics based on gender, age, latest education, work unit, and years of service. The detailed characteristics of the respondents are presented in Table 1.

Testing the measurement model or the outer model is carried out to determine the validity and reliability of the indicators that make up each latent variable. The goodness of fit test of the outer model uses three criteria, namely convergent validity, discriminant validity, composite reliability, and Cronbach's alpha. The PLS analysis result model can be presented in Figure 2 as follows.

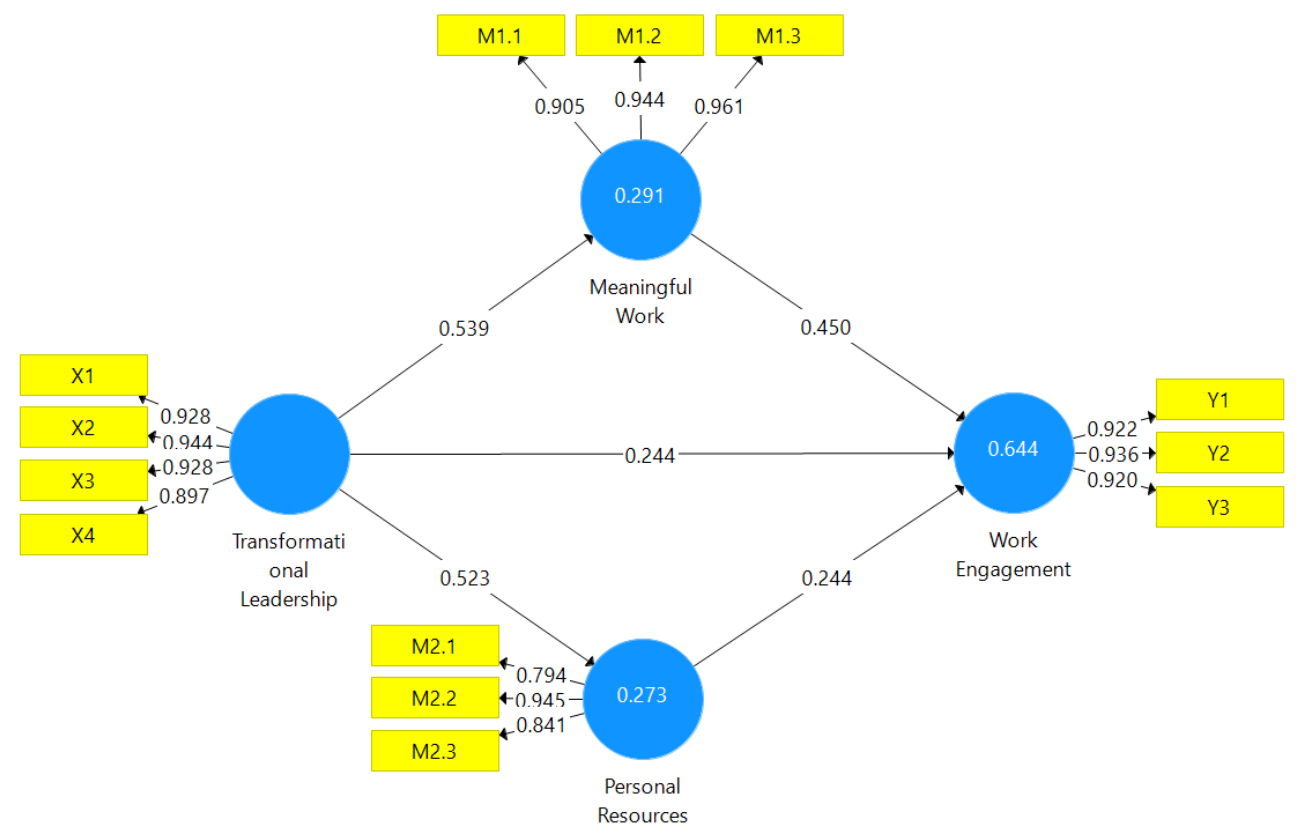

Figure 2 - Model Results of PLS Analysis

Table 2 - Convergent Validity Test Results

\begin{tabular}{|l|l|l|l|l|}
\hline \multicolumn{1}{|c|}{$\mathrm{n} / \mathrm{n}$} & $\begin{array}{l}\text { Transformational } \\
\text { Leadership (X) }\end{array}$ & $\begin{array}{l}\text { Work } \\
\text { Engagement } \\
(\mathrm{Y})\end{array}$ & $\begin{array}{l}\text { Meaningful } \\
\text { Work (M1) }\end{array}$ & $\begin{array}{l}\text { Personal } \\
\text { Resources } \\
\text { (M2) }\end{array}$ \\
\hline Positive meaning in work (M1.1) & & & 0,905 & \\
\hline Meaning making through work (M1.2) & & & 0,944 & \\
\hline Greater good motivation (M1.3) & & & 0,961 & \\
\hline Self-efficacy (M2.1) & & & & 0,794 \\
\hline Organizational based self-esteem (M2.2) & & & & 0,945 \\
\hline Optimismn (M2.3) & & & & 0,841 \\
\hline Idealized influence (X1) & 0,928 & & & \\
\hline Inspirational motivation (X2) & 0,944 & & & \\
\hline Intellectual stimulation (X3) & 0,928 & & & \\
\hline Individualized consideration (X4) & 0,897 & & & \\
\hline Vigor (Y1) & & 0,922 & & \\
\hline Dedication (Y2) & & 0,936 & & \\
\hline Absorption (Y3) & & 0,920 & & \\
\hline
\end{tabular}

Source: Primary data processed, 2021.

Table 2 shows that all construct indicator outer loading values have values greater than 0.50. Thus it can be stated that this measurement meets the requirements of convergent validity. The results of the discriminant validity test using the loading factor are presented in Table 3. 
Table 3 - Discriminant Validity Test Results Using Loading Factor

\begin{tabular}{|l|l|l|l|l|}
\hline \multicolumn{1}{|c|}{$\mathrm{n} / \mathrm{n}$} & $\begin{array}{l}\text { Transformational } \\
\text { Leadership (X) }\end{array}$ & $\begin{array}{l}\text { Work } \\
\text { Engagement } \\
\text { (Y) }\end{array}$ & $\begin{array}{l}\text { Meaningful } \\
\text { Work (M1) }\end{array}$ & $\begin{array}{l}\text { Personal } \\
\text { Resources } \\
\text { (M2) }\end{array}$ \\
\hline Positive meaning in work (M1.1) & 0,501 & 0,632 & 0,905 & 0,542 \\
\hline Meaning making through work (M1.2) & 0,500 & 0,704 & 0,944 & 0,617 \\
\hline Greater good motivation (M1.3) & 0,514 & 0,736 & 0,961 & 0,648 \\
\hline Self-efficacy (M2.1) & 0,342 & 0,329 & 0,308 & 0,794 \\
\hline Organizational based self-esteem (M2.2) & 0,525 & 0,601 & 0,569 & 0,945 \\
\hline Optimismn (M2.3) & 0,451 & 0,692 & 0,697 & 0,841 \\
\hline Idealized influence (X1) & 0,928 & 0,552 & 0,467 & 0,474 \\
\hline Inspirational motivation (X2) & 0,944 & 0,566 & 0,510 & 0,474 \\
\hline Intellectual stimulation (X3) & 0,928 & 0,618 & 0,535 & 0,491 \\
\hline Individualized consideration (X4) & 0,897 & 0,531 & 0,477 & 0,494 \\
\hline Vigor (Y1) & 0,589 & 0,922 & 0,722 & 0,646 \\
\hline Dedication (Y2) & 0,537 & 0,936 & 0,721 & 0,629 \\
\hline Absorption (Y3) & 0,582 & 0,920 & 0,600 & 0,556 \\
\hline
\end{tabular}

Source: Primary data processed, 2021.

Table 3 shows that all cross loading values for each construct indicator have values greater than 0.50 . Thus it can be stated that this measurement meets the requirements of discriminant validity.

The results of the discriminant validity test using AVE are presented in Table 4 . Table 4 shows that all AVE values are greater than 0.50 . Thus it can be stated that this measurement meets the requirements of discriminant validity.

Table 4 - Discriminant Validity Test Results Using AVE

\begin{tabular}{|c|c|}
\hline $\mathrm{n} / \mathrm{n}$ & Average Variance Extracted (AVE) \\
\hline Transformational Leadership $(\mathrm{X})$ & 0,855 \\
\hline Work Engagement (Y) & 0,857 \\
\hline Meaningful Work (M1) & 0,877 \\
\hline Personal Resources (M2) & 0,743 \\
\hline
\end{tabular}

Source: Primary data processed, 2021.

Discriminant validity in this study can also be seen from the value of the root square of average variance extracted (RSAVE) of each construct with a correlation between one construct and another. It can be seen from the square root value of AVE in bold which has a greater value than the correlation between constructs. The results of the discriminant validity test using RSAVE are presented in Table 5.

Table 5 - Discriminant Validity Test Results Using RSAVE

\begin{tabular}{|l|l|l|l|l|}
\hline \multicolumn{1}{|c|}{$\mathrm{n} / \mathrm{n}$} & $\begin{array}{l}\text { Transformational } \\
\text { Leadership (X) }\end{array}$ & $\begin{array}{l}\text { Work } \\
\text { Engagement } \\
(\mathrm{Y})\end{array}$ & $\begin{array}{l}\text { Meaningful } \\
\text { Work (M1) }\end{array}$ & $\begin{array}{l}\text { Personal } \\
\text { Resources (M2) }\end{array}$ \\
\hline Transformational Leadership (X) & 0,924 & & & \\
\hline Work Engagement (Y) & 0,614 & 0,926 & & \\
\hline Meaningful Work (M1) & 0,539 & 0,739 & 0,937 & \\
\hline Personal Resources (M2) & 0,523 & 0,662 & 0,645 & 0,862 \\
\hline
\end{tabular}

Source: Primary data processed, 2021.

Table 5 shows that all RSAVE values are greater than 0.50 . Thus it can be stated that this measurement meets the requirements of discriminant validity.

The last part is testing the outer model using composite reliability criteria and Cronbach's alpha, which is testing the reliability value between the indicator blocks of the constructs that form it. The results of the validity test of composite reliability and Cronbach's alpha are presented in Table 6. 
Table 6 - Composite Reliability Validity Test Results

\begin{tabular}{|l|l|l|l|}
\hline \multicolumn{1}{|c|}{$\mathrm{n} / \mathrm{n}$} & Cronbach's Alpha & rho_A & Composite Reliability \\
\hline Transformational Leadership $(\mathrm{X})$ & 0,943 & 0,945 & 0,959 \\
\hline Work Engagement $(\mathrm{Y})$ & 0,917 & 0,921 & 0,947 \\
\hline Meaningful Work (M1) & 0,930 & 0,934 & 0,955 \\
\hline Personal Resources (M2) & 0,831 & 0,875 & 0,896 \\
\hline
\end{tabular}

Table 6 shows that all Cronbach's alpha values and composite reliability values for each construct are greater than 0.70 . Thus, it can be stated that all indicators are indeed a measure of their respective constructs.

Testing of the structural model (structural model) or inner model is carried out to see the accuracy of the model by paying attention to the relationship between constructs, significance value, and $R$-square $\left(R^{2}\right)$ of the research model. The goodness of fit test of the inner model uses two criteria, namely $R$-square $\left(R^{2}\right)$ and $Q$-square predictive relevance $\left(Q^{2}\right)$. The results of the R-square test $\left(R^{2}\right)$ are presented in Table 7 .

Table 7 - R-square Test Results

\begin{tabular}{|l|l|l|}
\hline \multicolumn{1}{|c|}{$\mathrm{n} / \mathrm{n}$} & $R$-square $\left(\mathrm{R}^{2}\right)$ & $R$-square Adjusted \\
\hline Work Engagement (Y) & 0,644 & 0,634 \\
\hline Meaningful Work (M1) & 0,291 & 0,284 \\
\hline Personal Resources (M2) & 0,273 & 0,267 \\
\hline
\end{tabular}

Source: Primary data processed, 2021.

Based on Table 7 , it shows that the R-square $\left(R^{2}\right)$ value for the transformational leadership variable on work engagement is 0.644 . This shows that transformational leadership has an effect of 0.644 (64.4 percent) on work engagement. The R-square $\left(R^{2}\right)$ value of 0.644 is a fairly strong model, meaning that the transformational leadership variable is able to explain the work engagement variable by 64.4 percent and the remaining 35.6 percent is explained by other factors outside the model. The value of R-square $\left(R^{2}\right)$ for the transformational leadership variable on meaningful work is 0.291 . This shows that transformational leadership has an effect of 0.291 (29.1 percent) on meaningful work. The Rsquare $\left(R^{2}\right)$ value of meaningful work is 0.291 including a fairly weak model, meaning that the transformational leadership variable is able to explain the meaningful work variable by 29.1 percent and the remaining 70.9 percent is explained by other factors outside the model. The value of $R$-square $\left(R^{2}\right)$ for the transformational leadership variable on personal resources is 0.273 . This shows that transformational leadership has an influence of 0.273 (27.3 percent) on personal resources. The R-square $\left(R^{2}\right)$ value of personal resources is 0.273 including a fairly weak model, meaning that the transformational leadership variable is able to explain the personal resources variable by 27.3 percent and the remaining 72.7 percent is explained by other factors outside the model.

Testing the inner model can also be done by looking at the $Q$-square value which is the goodness of fit model test. The calculation results show that the value of $Q$-square predictive relevance $(\mathrm{Q} 2)$ is 0.817 . These results indicate that the value of $\mathrm{Q}$-square predictive relevance (Q2) is greater than 0, meaning that the model has predictive relevance or a feasible model has relevant predictive values. The results of this test prove that the structural model is classified as very good. In other words, 81.7 percent of the variation of endogenous constructs can be explained by variations of exogenous constructs, the remaining 18.3 percent is explained by other factors outside the model.

Testing the hypothesis on the effect of transformational leadership on work engagement resulted in a path coefficient value of 0.244 and a P-Value value of 0.002 which was smaller than 0.05 . This means that transformational leadership has a positive and significant effect on work engagement. So that hypothesis $1(\mathrm{H} 1)$ which states that transformational leadership has a significant effect on work engagement is accepted. Thus, it can be concluded that the better the transformational leadership, the greater the work engagement. Transformational leadership as measured by ideal influence, inspiring 
motivation, intellectual stimulation, and individual consideration has been well managed by AirNav Indonesia Denpasar Branch so that it contributes to work engagement which includes vigor, dedication, and absorption.

Table 8 - Direct Effect Test Results

\begin{tabular}{|l|l|l|l|}
\hline $\mathrm{n} / \mathrm{n}$ & Path Coefficient & T-Statistics & P-Value \\
\hline Transformational Leadership $(\mathrm{X}) \rightarrow$ Work Engagement $(\mathrm{Y})$ & 0,244 & 2,867 & 0,002 \\
\hline Transformational Leadership $(\mathrm{X}) \rightarrow$ Meaningful Work (M1) & 0,539 & 5,849 & 0,000 \\
\hline Transformational Leadership $(\mathrm{X}) \rightarrow$ Personal Resources (M2) & 0,523 & 7,100 & 0,000 \\
\hline Meaningful Work (M1) $\rightarrow$ Work Engagement $(\mathrm{Y})$ & 0,450 & 4,746 & 0,000 \\
\hline Personal Resources (M2) $\rightarrow$ Work Engagement $(\mathrm{Y})$ & 0,244 & 2,649 & 0,004 \\
\hline
\end{tabular}

Source: Primary data processed, 2021.

Testing the hypothesis on the effect of meaningful work on work engagement produces a path coefficient value of 0.450 and a P-Value value of 0.000 which is smaller than 0.05 . This means that meaningful work has a positive and significant effect on work engagement. So that hypothesis $2(\mathrm{H} 2)$ which states that meaningful work has a significant effect on work engagement is accepted. Thus, it can be concluded that the higher the sense of meaningful work, the more work engagement will increase. Meaningful work as measured by positive meaning in work, meaning making through work, and greater good motivation are very high owned by AirNav Indonesia Denpasar Branch employees so that they contribute to work engagement which includes vigor, dedication, and absorption.

Hypothesis testing on the influence of personal resources on work engagement resulted in a path coefficient value of 0.244 and a $P$-Value value of 0.004 which was smaller than 0.05 . This means that personal resources have a positive and significant effect on work engagement. So that hypothesis $3(\mathrm{H} 3)$ which states that personal resources have a significant effect on work engagement is accepted. Thus, it can be concluded that the higher the personal resources, then the work engagement will increase. The employees of AirNav Indonesia Denpasar Branch have very high personal resources as measured by self-efficacy, organizational-based self-esteem, and optimism, so they contribute to work engagement which includes vigor, dedication, and absorption.

Hypothesis testing on the effect of transformational leadership on meaningful work produces a path coefficient value of 0.539 and a P-Value value of 0.000 which is smaller than 0.05. This means that transformational leadership has a positive and significant effect on meaningful work. So that hypothesis $4(\mathrm{H} 4)$ which states that transformational leadership has a significant effect on meaningful work is accepted. Thus, it can be concluded that the better the transformational leadership, the greater the sense of meaningful work will be. Transformational leadership as measured by idealized influence, inspirational motivation, intellectual stimulation, and individual consideration has been well managed by AirNav Indonesia Denpasar Branch so that it contributes to a sense of meaningful work which includes positive meaning in work, meaning making through work, and greater good motivation. .

Hypothesis testing on the influence of transformational leadership on personal resources resulted in a path coefficient value of 0.523 and a P-Value value of 0.000 which was smaller than 0.05 . This means that transformational leadership has a positive and significant effect on personal resources. So that hypothesis $5(\mathrm{H} 5)$ which states that transformational leadership has a significant effect on personal resources is accepted. Thus, it can be concluded that the better the transformational leadership, the more personal resources will be. Transformational leadership as measured by idealized influence, inspirational motivation, intellectual stimulation, and individual consideration has been well managed by AirNav Indonesia Denpasar Branch so that it contributes to personal resources which include self-efficacy, organizational-based self-esteem, and optimism.

There are two indirect influence hypotheses that were tested using Partial Least Square (PLS). The results of testing the indirect effect on the structural equation analysis are presented in Table 9. 
Table 9 - Indirect Effect Test Results

\begin{tabular}{|l|l|l|l|}
\hline \multicolumn{1}{|c|}{$\mathrm{n} / \mathrm{n}$} & Path Coefficient & T-Statistics & $P$-Value \\
\hline $\begin{array}{l}\text { Transformational Leadership }(\mathrm{X}) \rightarrow \text { Meaningful Work (M1) } \rightarrow \text { Work } \\
\text { Engagement }(\mathrm{Y})\end{array}$ & 0,242 & 3,896 & 0,000 \\
\hline $\begin{array}{l}\text { Transformational Leadership }(\mathrm{X}) \rightarrow \text { Personal Resources (M2) } \rightarrow \\
\text { Work Engagement }(\mathrm{Y})\end{array}$ & 0,128 & 2,539 & 0,006 \\
\hline
\end{tabular}

Source: Primary data processed, 2021.

Hypothesis testing on the effect of transformational leadership on work engagement mediated by meaningful work resulted in a path coefficient value of 0.242 and a P-Value value of 0.000 which was smaller than 0.05 . This means that transformational leadership has a positive and significant effect on work engagement mediated by meaningful work. So that hypothesis $6(\mathrm{H} 6)$ which states that meaningful work acts as a mediator on the influence of transformational leadership on work engagement is accepted. Thus, it can be concluded that the better the transformational leadership felt by employees, the sense of meaningful work that employees have will increase so that it will increase work engagement in the company.

Hypothesis testing on the effect of transformational leadership on work engagement mediated by personal resources resulted in a path coefficient value of 0.128 and a P-Value value of 0.006 which was smaller than 0.05 . This means that transformational leadership has a positive and significant effect on work engagement mediated by personal resources. So that hypothesis $7(\mathrm{H} 7)$ which states that personal resources act as a mediator on the influence of transformational leadership on work engagement is accepted. Thus, it can be concluded that the better the transformational leadership felt by employees, the personal resources owned by employees will increase so that it will increase work engagement in the company.

Testing the mediating variable in this study is to examine the role of meaningful work variables and personal resources in mediating the effect of transformational leadership on work engagement. The test of the mediating variable in this study can be seen in Table 10 .

Table 10 - Mediation Test Results Based on VAF

\begin{tabular}{|l|l|l|l|l|}
\hline \multicolumn{1}{|c|}{$\mathrm{n} / \mathrm{n}$} & Path Coefficient & T-Statistics & $P$-Value & VAF \\
\hline $\begin{array}{l}\text { Transformational Leadership }(\mathrm{X}) \rightarrow \text { Meaningful Work (M1) } \rightarrow \\
\text { Work Engagement (Y) }\end{array}$ & 0,242 & 3,896 & 0,000 & 0,498 \\
\hline $\begin{array}{l}\text { Transformational Leadership }(\mathrm{X}) \rightarrow \text { Personal Resources (M2) } \\
\rightarrow \text { Work Engagement }(\mathrm{Y})\end{array}$ & 0,128 & 2,539 & 0,006 & 0,344 \\
\hline
\end{tabular}

Table 10 shows that the mediating role of the meaningful work variable has a VAF value of 0.498 (49.80 percent). This VAF value is in the range of $20 \%-80 \%$. That is, the meaningful work variable is classified as partial mediation. This shows that meaningful work can partially mediate the effect of transformational leadership on work engagement. In other words, the better the transformational leadership felt by the employee, the more meaningful the employee's sense of work will be so that the employee will be more attached to the work in the company. The mediating role of the personal resource variable has a VAF value of 0.344 (34.40 percent). This VAF value is in the range of $20 \%-80 \%$. That is, the personal resource variable is classified as a partial mediation. This shows that personal resources can partially mediate the effect of transformational leadership on work engagement. In other words, the better the transformational leadership felt by employees, the personal resources owned by employees will increase so that employees will be more attached to work in the company.

Based on the explanation above, it can be concluded that the employees of AirNav Indonesia Denpasar Branch assess transformational leadership in the form of ideal influence, inspiring motivation, intellectual stimulation, and individual consideration to play a major role in increasing their sense of meaningful work and personal resources, thereby increasing their sense of belonging work engagement in the company. 


\section{THEORETICAL IMPLICATIONS}

The results of this study have shown that transformational leadership has a positive and significant effect on work engagement, transformational leadership has a positive and significant effect on meaningful work, transformational leadership has a positive and significant effect on personal resources, meaningful work has a positive and significant effect on work engagement, personal resources positive and significant effect on work engagement, meaningful work is able to mediate the effect of transformational leadership on work engagement, and personal resources are able to mediate the effect of transformational leadership on work engagement. Based on these findings, the results of this study are able to enrich the development of human resource management science, especially related to work engagement and support other related empirical studies on the effect of transformational leadership on work engagement mediated by meaningful work and personal resources.

\section{MANAGERIAL IMPLICATIONS}

The results of this study indicate that the transformational leadership variable has the highest influence on meaningful work, followed by the influence of transformational leadership on personal resources. Thus, the management should pay more attention to the transformational leadership at AirNav Indonesia Denpasar Branch. Because with better transformational leadership, employees will have a sense of meaningful work and high personal resources, so that it will increase work engagement in the company.

\section{RESEARCH LIMITATIONS}

This study is only limited to examining the effect of transformational leadership variables, meaningful work, and personal resources on work engagement. So it can not examine more deeply about the factors outside these variables. Therefore, further research is expected to be able to examine more deeply about work engagement using other influential variables.

\section{CONCLUSION}

Transformational leadership has a positive and significant effect on work engagement. This means that the better the transformational leadership felt by AirNav Indonesia Denpasar Branch employees, the higher the employee's work engagement. Vice versa, the worse the transformational leadership felt by AirNav Indonesia Denpasar Branch employees, the lower the employee's work engagement.

Meaningful work has a positive and significant effect on work engagement. This means that the higher the meaningful work perceived by the employees of AirNav Indonesia Denpasar Branch, the higher the employee's work engagement. Vice versa, the lower the meaningful work felt by AirNav Indonesia Denpasar Branch employees, the lower the employee's work engagement.

Personal resources have a positive and significant effect on work engagement. This means that the higher the personal resources of the employees of AirNav Indonesia Denpasar Branch, the higher the employee's work engagement. Vice versa, the lower the personal resources of AirNav Indonesia Denpasar Branch employees, the lower the employee's work engagement.

Transformational leadership has a positive and significant effect on meaningful work. This means that the better the transformational leadership perceived by the employees of AirNav Indonesia Denpasar Branch, the greater the sense of meaningful work will be. Vice versa, the worse the transformational leadership felt by AirNav Indonesia Denpasar Branch employees, the lower the sense of meaningful work. 
Transformational leadership has a positive and significant effect on personal resources. This means that the better the transformational leadership felt by AirNav Indonesia Denpasar Branch employees, the more personal resources will be. Vice versa, the worse the transformational leadership felt by AirNav Indonesia Denpasar Branch employees, the lower the personal resources.

Meaningful work mediates the effect of transformational leadership on partial mediation. This means that when the leader shows a good transformational leadership style, it can increase the meaningful work of employees which then has an impact on increasing work engagement.

Personal resources mediate the effect of transformational leadership on partial mediation. This means that when the leader shows a good transformational leadership style, it can increase the personal resources of employees which then has an impact on increasing work engagement.

\section{SUGGESTIONS}

Based on the analysis of research results, discussions and conclusions, there are several suggestions that can be used as consideration in determining policies to increase work engagement at AirNav Indonesia Denpasar Branch in the future, including:

1. To be able to increase employee work engagement at AirNav Indonesia Denpasar Branch, it is recommended for management to increase the sense of meaningful work on the positive meaning in work indicator, which has found a career that is in accordance with what is expected and a job that has a satisfying goal In addition, it is also necessary to increase employees personal resources on organizational-based self-esteem indicators, which are seen as people who are considered and are considered efficient in working in the company;

2. In order to increase the sense of meaningful work and personal resources for employees at AirNav Indonesia Denpasar Branch, it is recommended for the management to improve transformational leadership on the indicator of idealized influence, namely always admiring the leadership in the company. In addition, it is also necessary to improve the indicators of individual considerations, namely the leadership in the company always spends time to foster and give special attention to subordinates;

3. Further research can examine constructs other than transformational leadership, meaningful work, and personal resources to be able to identify more deeply about work engagement.

\section{REFERENCES}

1. Afiani, R., Surachim, A., and Masharyono, M. 2019. Peran kepemimpinan transformasional dalam meningkatkan employee engagement and dampaknya pada kinerja pegawai. Journal of Business Management Education. Vol. 4, No. 1. Hal. 1-12.

2. Anindita, A., and Etikariena, A. 2020. Hubungan trait mindfulness and keterikatan kerja dengan melibatkan peran mediasi modal psikologis. Jurnal Psikogenesis. Vol. 8, No. 1. Hal. 1-17.

3. Armstrong, M. 2011. Armstrong's Handbook of Strategic Human Resource Management. $5^{\text {th }}$ Edition. United Kingdom: Kogan Page.

4. Arnold, K. A., Turner, N., Barling, J., Kelloway, K. E., and McKee, C. M. 2007. Transformational leadership and psychological well-being: The mediating role of meaningful work. Journal of Occupational Health Psychology. Vol. 12, No. 3. pp. 193-203.

5. Ayu, D. R., Maarif, S., and Sukmawati, A. 2015. Pengaruh job demands, job resources and personal resources terhadap work engagement. Jurnal Aplikasi Bisnis and Manajemen (JABM). Vol. 1, No. 1. Hal. 12-22. 
6. Bakker, A. B., and Demerouti, E. 2007. The job demands-resources model: State of the art. Journal of Managerial Psychology. Vol. 22, No. 3. Pp. 309-328.

7. Bakker, A. B., and Demerouti, E. 2008. Towards a model of work engagement. Journal of Managerial Psychology. Career Development International. Vol. 13, No. 3. Pp. 209-223.

8. Bakker, A. B., Schaufeli, B. W., Leiter, P. M., and Taris, W. T. 2008. Work engagement: An emerging concept in occupational health psychology. Journal Work and Stress An International Journal of Work, Health and Organizations. Vol. 22. Pp. 187-200.

9. Bakker, A. B., Albrecht, L. S., and Leiter, P. M. 2011. Key questions regarding work engagement. European Journal of Work and Organizational Psychology. Vol. 20, No. 1. Pp. 4-28.

10. Balwant, P. T., Mohammed, R., and Singh, R. 2020. Transformational leadership and employee engagement in Trinidad's service sector - The role of job resources. International Journal of Emerging Markets. Vol. 15, No. 4. Pp. 691-715.

11. Blau, P. M. 1964. Justice in social exchange. Sociological Inquiry. Vol. 34, No. 2. pp. 193-206.

12. Chalofsky, N. 2003. An emerging construct for meaningful work. Human Resource Development International. Vol. 6, No. 1. Pp. 69-83.

13. Demirtas, O., Bickes, M. D., Yener, S., and Karaca, M. 2019. The influence of transformational leadership in organizations: The mediating role of meaningful work. Journal of Economy Culture and Society. Vol. 61. Pp. 153-172.

14. Geldenhuys, M., Laba, K., and Venter, C. M. 2014. Meaningful work, work engagement and organisational commitment. SA Journal of Industrial Psychology. Vol. 40, No. 1. pp. 1-10.

15. Ghadi, M. Y., Fernando, M., and Caputi, P. 2013. Transformational leadership and work engagement: The mediating effect of meaning in work. Leadership \& Organization Development Journal. Vol. 34, No. 6. Pp. 532-550.

16. Goodwin, V. L., Wofford, C. J., and Whittington, L. J. 2001. A theoretical and empirical extension to the transformational leadership construct. Journal of Organizational Behavior. Vol. 22, No. 7. Pp.759-774.

17. Handayani, W. P. P., and Pitoyo, J. D. 2018. Pengaruh transformational leadership terhadap work engagement yang dimediasi oleh meaning in work and personal resource. Jurnal Ekonomi Universitas Kadiri. Vol.3, No. 2. Hal. 105-117.

18. Heuvel, M. V. D., Demerouti, E., Schaufeli, B. W., and Bakker, B. A. 2010. Personal resource and work engagement in the face of change. Contemporary Occupational Health Psychology: Global Perspectives on Research and Practice. Vol. 1. Pp. 124-150.

19. Hobfoll, S. E., Johnson, J. R., Ennis, N., and Jackson, P. A. 2003. Resource loss, resource gain, and emotional outcomes among inner city women. Journal of Personality and Social Psychology. Vol. 84, No. 3. Pp. 632-643.

20. Kahn, W. A. 1990. Psychological conditions of personal engagement and disengagement at work. The Academy of Management Journal. Vol. 33, No. 4. pp. $692-724$.

21. Luthans, F., Avolio, B. J., Avey, J. B., and Norman, S. M. 2007. Positive psychological capital: Measurement and relationship with performance and satisfaction. Personnel Psychology. Vol. 60. Pp. 541-572.

22. Macey, W. H., and Schneider, B. 2008. The meaning of employee engagement. Industrial and Organizational Psychology. Vol. 1, No. 1. Pp. 3-30.

23. Majid, A. S., and Mahdani. 2019. Pengaruh makna kerja terhadap komitmen afektif dengan variabel pemediasi keterikatan kerja pada karyawan Bank Mandiri area Banda Aceh. Jurnal IImiah Mahasiswa Ekonomi Manajemen. Vol. 4, No. 2. Hal. 273-286.

24. Mat, N., Jansriboot, P., and Mat, N. 2019. Big five personality, transformational leadership, psychological safety, and employee engagement. Jurnal Pengurusan. Vol. 56. Pp.1-19.

25. Maulana, H., and Verawati. 2014. Pengaruh gaya kepemimpinan transformasional terhadap keterikatan karyawan: Studi pada PT. Pertamina (Persero). Jurnal Penelitian and Pengukuran Psikologi. Vol. 3, No. 2. Hal. 47-52. 
26. May, D. R., Gilson, R. L., and Harter, L. M. 2004. The psychological conditions of meaningfulness, safety and availability and the engagement of the human spirit at work. Journal of Occupational and Organizational Psychology. Vol. 77, No. 1. Pp. 11-37.

27. Pitoyo, D. J., and Sawitri, S. R. H. 2016. Transformational leadership, meaning in work, leader member exchange $(\operatorname{Imx})$, job performance and work engagement. Jurnal Bisnis \& Manajemen. Vol. 16, No. 2. Hal. 15-34.

28. Rahman, Z. 2015. The role of meaningful work in transformational leadership and work outcomes relationship. International Journal of Economics and Management Engineering. Vol. 9, No. 9, Pp. 3304-3310.

29. Robbins, S. P., and Judge, A. T. 2015. Perilaku Organisasi. Edisi ke-16. Terjemahan. Jakarta: Salemba Empat.

30. Schaufeli, W. B. 2012. Work engagement. What do we know and where do we go. Romanian Journal of Applied Psychology. Vol. 14, No. 1. Pp. 3-10.

31. Schaufeli, W. B., Salanova, M., Gonzalez-Roma, V. and Bakker, A. B. 2002. The measurement of engagement and burnout: A two-sample confirmatory factor-analytic approach. Journal of Happiness Studies. Vol. 3. Pp. 71-92.

32. Siahaan, L. F., and Gatari, E. 2020. Searching for meaning: The mediating role of work engagement in the relationship between meaningful work and turnover intention of Millennials. Psikohumaniora: Jurnal Penelitian Psikologi. Vol. 5, No. 1. Pp. 15-28.

33. Siswanto, and Lestari, E. A. 2019. The determinant of employee engagement. Iqtishadia: Jurnal Ekonomi and Perbankan Syariah. Vol. 6, No. 2. Hal. 119-130.

34. Sofiah, D., and Kurniawan, G. 2019. Hubungan self-efficacy dengan employee work engagement pada karyawan. Jurnal Fenomena. Vol. 28, No. 1. Hal. 54-61.

35. Steger, M. F., Dik, J. B., and Duffy, D. R. 2012. Measuring meaningful work: The work and meaning inventory (WAMI). Journal of Career Assessment. Vol. 20, No. 3. pp. 322-337.

36. Wingerden, J. V., Derks, D., and Bakker, B. A. 2015. The impact of personal resources and job crafting interventions on work engagement and performance. Human Resource Management. Vol. 56, No. 1. Pp. 51-67.

37. Xanthopoulou, D., Bakker, B. A., Demerouti, E., and Schaufeli, B. W. 2009. Reciprocal relationships between job resources, personal resources, and work engagement. Journal of Vocational Behavior. Vol. 74. Pp. 235-244.

38. Yukl, G. 2015. Kepemimpinan Dalam Organisasi. Edisi Ke-7. Terjemahan. Jakarta: PT Indeks. 